\title{
On the Review
}

Helsinki Law Review is published and edited by Finnish undergraduate law students. Its primary purpose is to provide Finnish law students with a forum for practicing their skills in academic writing and assessment as well as an opportunity to follow and participate in the work of their peers and seniors.

The Review is currently planned to be published twice a year. The Review is prepared to publish articles and other contributions in Finnish, Swedish and English. English Abstracts are provided for content not fully written in English. At the present, the Review is not available for subscription, and printed copies are distributed for free.

Helsinki Law Review is supervised and counselled by an Academic Council that consists of a number of senior academic staff members in the University of Helsinki Faculty of Law. Each article is evaluated anonymously by a referee chosen among academic professionals in different Finnish Universities. A referee evaluating an article written by an undegraduate student is advised of the author's background.

The Review may be cited as Hel. L. Rev.

\section{From the Editors}

When Helsinki Law Review was published and launched in March 2008, it received extensive publicity, keen interest and several inquiries from various academic and professional directions as well as individual lawyers. The print of the first issue ran out steadily during the following months. Eventually, the member list of the Board of Editors was reinforced and reconstructed, with several new members joining the Board.

As already stated by the Board in the first issue, the primary aim of the Board has been (and still is) the establishment of a tradition - to make sure the Review becomes a steady, established publication. Finally, the 2008 issue of Helsinki Law Review is finished. One step closer to the goal, the Board remains ever thankful to the contributing writers and referees as well as the Academic Council for their support. Due to the keen interest and good fortune that the Review has received thus far, we may now be closer to the point where we can begin to design the natural upcoming improvements to the Review's content, such as book reviews and our very own website.

This issue of Helsinki Law Review is published near the end of the autumn term, one of our aims being to shift the publication schedule this way to better match the academic terms of the University of Helsinki.

Although Helsinki Law Review is characteristically intended to be a publication for distinguished law articles, we wish to remain open for all ideas holding strong legal significance. In this issue, B.Sc. Lauri Rantakari (Helsinki School of Economics) has written an article on network neutrality, his contribution being our first step in creating an open collaboration with other academic communities besides our own.

\section{Ville Komulainen}

Editor-in-chief 